\title{
Economic Implications of Fethullahist Terrorist Organization and Parallel State Constitution on Turkish Economy
}

\author{
Levent Aydin ${ }^{1, *}$ \\ ${ }^{1}$ Faculty of Political Sciences, Social Sciences University of Ankara, Turkey \\ *Correspondence: Faculty of Political Sciences, Social Sciences University of Ankara, \\ Turkey. E-mail: levent.aydin@asbu.edu.tr
}

Received: August 11, 2017 Accepted: August 25, 2017 Published: September 7, 2017

doi: 10.5296/rae.v9i3.11667 URL: https://doi.org/10.5296/rae.v9i3.11667

\begin{abstract}
This study attempts to indicate the economic implications of the Fethullahçı Terrorist Organization and the Parallel State Constitution (FETO / PDY) on the Turkish economy. Until the July 15 coup attempt, it seems unlikely that the effects on the economy will be revealed, given the fact that the organization behaves secretly and tactfully. Therefore, only the effects of the July 15 coup attempt on major variables in both the financial sector (daily exchange rate and interest rate) and the reel sector (production, capital movement, current account deficit and employment) can be analyzed in a descriptive method. The strong policy impact of the country's president and politicians, the police, the military, the bureaucracy, the business community, the political parties and the people's integration into the coup attempt has led to the least possible uncertainty of the coup attempt in the economy, resulting in a lasting and limited impact.
\end{abstract}

Keywords: FETO/PDY, July 15 Coup Attempt, Turkey, Macroeconomic indicators 


\section{Introduction}

Before starting the analysis of the effects of the Fethullahist Terrorist Organization and the Parallel State Constitution (FETO/PDY) on the Turkish economy, it is necessary to briefly mention the political structure and development of the terrorist organization. First of all, taking into consideration the activities of the FETO/PDY in Turkey, it is possible to distinguish three successive cycles;

In the first period, until the end of 2013, Fethullahist Terrorist Organization (FETO) under the leadership of Fethullah Gulen had been called as "Fethullah Gülen Community", "Fethullah Gülen Organization", "Fethullah Gülen Organization", "Camia", " Movement ", and "Volunteer Movement ".

In the second period, following the judicial coup attempt of 17 to 25 December against the ruler in 2013, they were referred to as "Parallel State Constitution (PDY)" and "Fethullahist Terrorist Organization (FETO)" by using more appropriate definitions and expressions for the essence, purpose, character and actions of the structure.

With the parallel state structure that it launched in Turkey in the third period, FETO/PDY demanded to break the democratic life in Turkey with a military coup once more after 15th of July 2016. The soldiers who were connected with the FETO/PDY attempted coup d'état with the military-civilian bureaucrats and the business world, academia and links to the media. However, the attempt of the coup was removed by President Recep Tayyip Erdoğan, especially, with public, police, soldiers and politicians and it took its place as an failed coup attempt in the history of Turkey's coup d'état.

In the first period from December 17 to December 25, 2013, political affiliation based on the principle of confidentiality and allegiance like FETO is yet to be fully revealed, but it is difficult to put the effects of the economy on a healthy basis. In addition, it can be said that the period of 17-25 December 2013 as "Parallel State Structuring" (PDY), until the failed coup attempt on July 15, 2016, was limited to the removal of public employees who were found to be in this structure. Therefore, the microeconomic effects that are economies in terms of seizure by the application of the state of emergency(Note 1) "OHAL" can be analyzed to the companies, institutions and organizations that have connected to the organization after the 15 July coup attempt and the changes in the macroeconomic indicators as well.

In the literature, there are few research articles on coup and coup attempts in Turkey, and some studies have tried to analyze the effects of the recent coup attempt on the economy. Karagol (2016), Kayhan and Kar (2016), Unay and Dilek (2017), and Tatliyer, M., And Gür, N., (2016) are given as examples of these studies. In addition to these studies, Parliamentary Investigation Commission of Grant National Assembly of Turkey released Fethullahist Terrorist Organization Report for the Determination of Measures to be Obtained from all the Directions of this Terror Organizational Activities with the Coup Attempt at 15 July 2016 in May 2017.

The rest of the study is structured as follows; the subsequent section comprises on 
macroeconomic implications of FETO/PDY on Turkey's economy. In section three, the microeconomic implications of the FETÖ/PDY on the companies and institutions are discussed. Conclusion is drawn in section four.

\section{Macroeconomic Implications of FETO/PDY on Turkey's Economy}

It is sufficient to look at various macroeconomic indicators that measure the performance of the Turkish economy, especially in the last two years, in order to demonstrate the economic implications of the FETO/ PDY. In the study, real GDP and economic growth, the number of tourists coming to the country, capital inflow and outflow, imports and exports, employment and unemployment rate, daily foreign exchange, interest rate and Stock Exchange Istanbul (BIST) index are taken as the selected indicators and their fluctuations indicate the economic effects of Turkey's economy.

\subsection{Change in Production and Economic Growth}

At the beginning of these indicators are the growth rates of the economic sectors in quarterly periods, which are shown in Table-1, and the GDP growth rate which shows the growth rate of the economy.

Table 1. Growth Rates of Economic Sectors and GDP(2009=100 Chained Value, Percentage Change)(Note 2)

\begin{tabular}{|c|c|c|c|c|c|c|c|c|c|c|c|c|}
\hline \multirow[b]{2}{*}{ Sectors } & \multirow{2}{*}{2013} & \multirow{2}{*}{2014} & \multicolumn{5}{|c|}{2015} & \multicolumn{5}{|c|}{2016} \\
\hline & & & $\mathbf{I}$ & II & III & IV & Toplam & $\mathbf{I}$ & II & III & IV & Toplam \\
\hline 1. Agricul., forestry, fishing & 2,3 & 0,6 & 6,5 & 8,8 & 16,3 & $-3,6$ & 9,1 & $-4,3$ & $-4,0$ & $-6,5$ & 1,3 & $-4,1$ \\
\hline 2. Industry & $\mathbf{9 , 0}$ & 5,6 & $\mathbf{0 , 8}$ & 5,4 & 3,8 & 9,6 & 5,0 & 8,1 & 6,0 & $-0,8$ & 5,0 & 4,5 \\
\hline Manufacturing & 9,3 & 6,1 & 2,6 & 5,7 & 4,0 & 10,7 & 5,9 & 7,7 & 6,3 & $-2,6$ & 4,4 & 3,9 \\
\hline Water supply, sewerage, wast. & 7,5 & 3,3 & $-7,4$ & 3,5 & 3,2 & 4,2 & 0,9 & 10,1 & 4,9 & 8,0 & 7,8 & 7,7 \\
\hline 3. Services & 8,3 & 6,1 & 3,8 & 6,4 & 4,0 & 7,2 & 5,4 & 4,0 & 5,8 & $-0,6$ & 3,0 & 3,0 \\
\hline Construction & 14,0 & 5,0 & $-2,1$ & 9,4 & 3,7 & 7,9 & 4,9 & 5,4 & 16,0 & 4,0 & 3,7 & 7,2 \\
\hline Trade,transport and accom. & 6,5 & 6,8 & 7,1 & 8,2 & 4,8 & 6,6 & 6,6 & 2,0 & 0,5 & $-7,4$ & 1,8 & $-0,8$ \\
\hline Information and communic. & 8,9 & 7,2 & 0,7 & 2,1 & 0,1 & 10,9 & 3,9 & 4,8 & 7,5 & 2,7 & 9,1 & 6,3 \\
\hline Fin. and insur.act. & 25,8 & 10,2 & 9,0 & 12,5 & 7,3 & 2,4 & 7,7 & 8,6 & 13,5 & $-1,3$ & 8,4 & 7,1 \\
\hline Real estate activities & 2,9 & 2,5 & 3,5 & 2,1 & 2,1 & 1,8 & 2,4 & 4,1 & 4,6 & 3,0 & 2,7 & 3,6 \\
\hline Professional, administ. serv. & 12,5 & 10,7 & 14,1 & 10,0 & 16,5 & 19,9 & 15,3 & 7,4 & 12,9 & 2,1 & 1,3 & 5,6 \\
\hline Public admin., edu..,health & 6,3 & 4,9 & $-0,8$ & 4,1 & 0,8 & 4,8 & 2,2 & 4,7 & 5,0 & 5,2 & 3,1 & 4,5 \\
\hline Other service activities & 8,2 & 6,8 & $-0,4$ & 0,3 & $-1,7$ & 1,3 & $-0,1$ & 2,6 & 1,6 & 0,1 & 3,8 & 2,1 \\
\hline 4. Sectors' Total $(1+2+3)$ & 8,0 & 5,6 & 3,2 & 6,3 & 5,7 & 7,0 & 5,6 & 4,7 & 5,3 & $-1,5$ & 3,3 & 2,8 \\
\hline 5. Taxes-Subsidies & 12,5 & 2,1 & 6,3 & 14,0 & 7,4 & 10,3 & 9,5 & 2,8 & 4,8 & 1,0 & 4,9 & 3,4 \\
\hline 6.GDP (Purch. Prices) $(4+5)$ & 8,5 & 5,2 & 3,5 & 7,2 & 5,9 & 7,4 & 6,1 & 4,5 & 5,3 & $-1,3$ & 3,5 & 2,9 \\
\hline
\end{tabular}

Source: Turkstat 
According to data from the Turkish Statistical Institute(TurkStat), the adverse effect of the July 15 coup attempt by the FETO/PDY on production is clearly visible after the 2009 crisis, with a contraction of $1.3 \%$ for the first time in 27 quarters, or nearly 7 years, until the third quarter of 2016. However, the economy grew by 4.5 percent in the first quarter of 2016 and by 5.3 percent in the second quarter of 2016, according to Table 1 . In addition, the economy was in the first place among the European economies with 6.1 percent growth in 2015 and 4.5 percent growth in the first quarter of 2016, and the Turkish economy, which cheered up, made an important move by dissolving the ice with Israel and Russia in foreign policy.

Regarding the sectors in which the shrinkage experienced in the third quarter of 2016 originated, "Trade, Transportation and Accommodation" sector is seen to have come to the fore with a contraction of $7.3 \%$ according to Table- 1 . This sector shrank by $0.8 \%$ in the third quarter of 2016, the first of the sectors that contributed to economic growth by growing at an average of $8 \%$ during the period from the 2009 crisis to the start of the coup attempt. The decrease in the number of tourists coming to the country among the main reasons for the decrease can be explained by the number of tourists shown in Table-2.

Table-2. Cumulative Number of Tourist Arrivals (1000 persons)

\begin{tabular}{lccccccccc}
\hline & $\mathbf{2 0 0 9}$ & $\mathbf{2 0 1 0}$ & $\mathbf{2 0 1 1}$ & $\mathbf{2 0 1 2}$ & $\mathbf{2 0 1 3}$ & $\mathbf{2 0 1 4}$ & $\mathbf{2 0 1 5}$ & $\mathbf{2 0 1 6}$ & $\mathbf{2 0 1 7}$ \\
\hline January & 752 & 810 & 976 & 982 & 1.105 & 1.147 & 1.251 & 1.170 & 1.055 \\
February & 1.651 & 1.764 & 2.055 & 1.979 & 2.373 & 2.499 & 2.634 & 2.411 & 2.215 \\
March & 2.858 & 3.178 & 3.673 & 3.440 & 4.214 & 4.351 & 4.530 & 4.063 & 3.802 \\
April & 4.609 & 4.923 & 5.964 & 5.608 & 6.665 & 7.003 & 6.967 & 5.817 & \\
May & 7.328 & 8.071 & 9.247 & 8.841 & 10.476 & 10.903 & 10.772 & 8.302 & \\
June & 10.591 & 11.571 & 13.027 & 12.724 & 14.550 & 15.238 & 14.895 & 10.740 & \\
July & 14.934 & 15.930 & 17.625 & 17.295 & 19.143 & 20.453 & 20.375 & 14.208 & \\
August & 18.694 & 19.649 & 21.702 & 21.766 & 24.089 & 25.736 & 25.506 & 17.391 & \\
September & 21.830 & 23.135 & 25.625 & 25.757 & 28.355 & 30.089 & 29.758 & 20.247 & \\
October & 24.447 & 25.975 & 28.665 & 28.808 & 31.758 & 33.528 & 33.059 & 22.697 & \\
November & 25.851 & 27.466 & 30.261 & 30.440 & 33.467 & 35.258 & 34.780 & 24.050 & \\
December & 27.077 & 28.632 & 31.456 & 31.783 & 34.910 & 36.838 & 36.245 & 25.352 & \\
\hline
\end{tabular}

Source: Ministry of Culture and Tourism

In a period when the tension between Turkey and Russia is being resolved in 2016 after the shooting down of Russian jet in November 2015, this time the FETÖ /PDY coup attempt and the geopolitical risks caused a great decrease in the number of tourists especially in summer. Approximately 36.2 million foreign tourists visited Turkey in 2015. When we reach this figure in 2016, it is about 25.3 million foreign tourists. Thus, the number of foreign tourists visiting Turkey in 2016 was approximately 30\% lower than in 2015 and there was a loss of 


\section{Macrothink Institute ${ }^{\mathrm{TM}}$}

approximately 8 billion dollars in tourism revenues. However, it is observed that the average number of tourists during the period from 2009 to 2014 increased by $5.5 \%$ per annum.

On the other hand, it can be said that the contraction in the production of the Turkish economy due to the July 15 coup is a share of the $8.4 \%$ decrease in the monthly industrial production index of July (percentage change from the same month of the previous year) shown in Figure-1. The industrial index for the third quarter of 2015 increased by average $0.5 \%$ and decreased by average $3.3 \%$ in the third quarter of 2016 compared to the same quarters of the previous year.

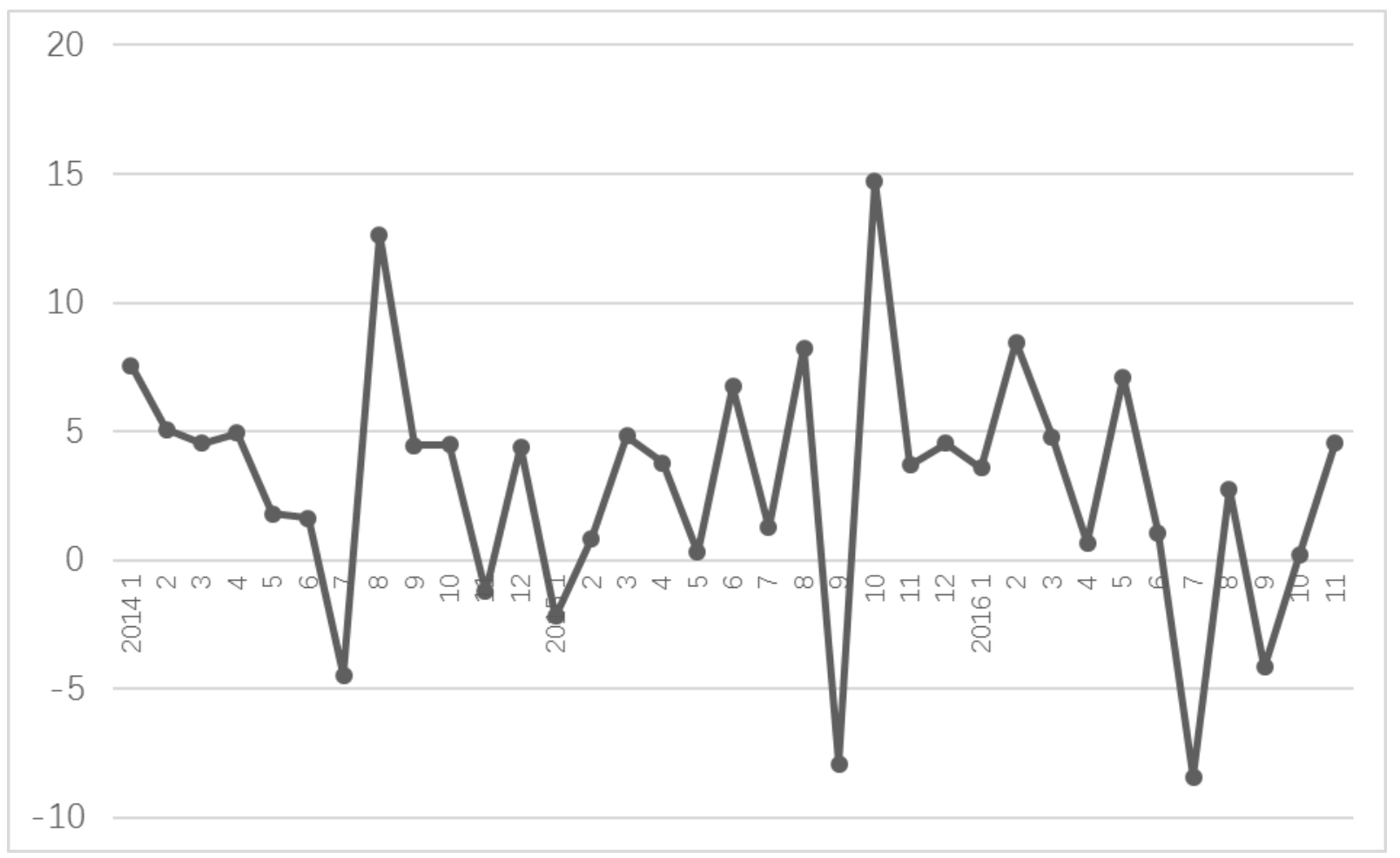

Figure 1. Monthly Industrial Production Index (percentage change from the same month of the previous year)

Source: Ministry of Development

\subsection{Change in Capital Flow}

The impulse coup attempt of FETÖ/PDY, which aimed at destroying the political and economic stability of Turkey, left a negative impact on the capital inflows and outflows in Turkey, but this adverse effect was exacerbated by three leading international credit rating agencies, Standard \& Poor's (S \& P), Moody's and Fitch. It can be said that these agencies has attempt to play an important role in Turkey's economy by downgrading of Turkey's note. S\&P announced that Turkey dropped its credit rating by one level five days after the coup attempt on July 15th. Turkey's credit rating was lowered from BB+ to BB, which is below the investment grade. In September, Moody's lowered Turkey's credit rating to Bal from the 
investment grade Baa3. Although Fitch negatively changed the outlook for Turkey on August 19, it did not update the BBB- note, which means Turkey can be invested.

Table 3. Foreign Capital Investments (Million USD)

\begin{tabular}{cccc}
\hline & Inflow & Outflow & Net \\
\hline 2009 & 6.266 & 82 & 6.184 \\
2010 & 6.256 & 35 & 6.221 \\
2011 & 16.136 & 1.991 & 14.145 \\
2012 & 10.761 & 633 & 10.128 \\
2013 & 9.890 & 568 & 9.322 \\
2014 & 8.631 & 261 & 8.370 \\
2015 & 12.074 & 364 & 11.710 \\
2016 & 6.887 & 609 & 6.278 \\
2017 Jan. & 280 & 0 & 280 \\
Feb. & 231 & 28 & 203 \\
March & 1.187 & 81 & 1.106 \\
\hline
\end{tabular}

Source: Ministry of Development

The most important economic risk to be created by the July 15 coup is to trigger the mechanism of "sudden stop" which draws attention to the report of the International Monetary Fund (IMF) in April 2016. The IMF explained that credit rating agencies could lower the investment grade of the country, causing capital outflows, which could make it difficult for companies to reverse their debts. The reflection of the problems that can be experienced in the debt payment of the companies to the banking sector can trigger an mechanism that could lead to accelerated capital outflows.

In this case, President Erdoğan and the policy maker of the economy have been influenced by the strong policy impact of these international credit rating agencies to be exposed to negative shocks on the economy and the IMF has underlined the "sudden stop" scenario.

\subsection{Change in Foreign Trade and Current Account Deficit}

The coup attempt also negatively affected the foreign trade of Turkey's economy. Both exports and imports fell more than expected in July. Turkey's exports fell by 11.5 percent in July to $\$ 9,855$ million while imports fell by 19.4 percent to $\$ 14,643$ million. Turkey has not exported to any country more than 1 billion dollars. While Britain was number one in exports with $\$ 982$ million, Germany took second place with $\$ 966$ million, Italy took third place with $\$ 550$ million. 
Table 4. Percentage Change in Exports (2009-2016)

\begin{tabular}{|c|c|c|c|c|c|c|c|c|}
\hline & \multicolumn{8}{|c|}{ year on year } \\
\hline & $10 / 09$ & $11 / 10$ & $12 / 11$ & $13 / 12$ & $14 / 13$ & $15 / 14$ & $16 / 15$ & $17 / 16$ \\
\hline January & $-0,7$ & 22,0 & 8,3 & 11,0 & 8,0 & $-0,8$ & $-22,4$ & 17,9 \\
\hline February & $-2,0$ & 21,7 & 16,8 & 5,4 & 5,4 & $-6,3$ & 1,1 & $-2,0$ \\
\hline March & 21,2 & 19,5 & 11,8 & $-0,7$ & 11,9 & $-14,7$ & 1,9 & 13,6 \\
\hline April & 24,3 & 26,4 & 6,4 & $-1,3$ & 7,2 & $-0,2$ & $-10,5$ & \\
\hline May & 33,4 & 11,7 & 20,0 & 1,1 & 3,0 & $-19,0$ & 9,2 & \\
\hline June & 14,6 & 18,9 & 16,6 & $-6,3$ & 3,9 & $-7,2$ & 7,7 & \\
\hline July & 5,6 & 24,0 & 8,2 & 1,8 & 2,2 & $-16,6$ & $-11,5$ & \\
\hline August & 8,7 & 31,9 & 14,1 & $-13,4$ & 2,4 & $-3,2$ & 7,3 & \\
\hline September & 5,1 & 20,7 & 20,5 & 0,8 & 4,0 & $-14,7$ & $-5,9$ & \\
\hline October & 8,6 & 8,6 & 10,8 & $-8,6$ & 7,0 & 2,7 & $-3,3$ & \\
\hline November & 5,4 & 18,1 & 24,1 & 3,3 & $-8,0$ & $-10,6$ & 9,5 & \\
\hline \multirow[t]{3}{*}{ December } & 17,6 & 5,5 & 1,0 & 4,5 & 0,7 & $-11,4$ & 8,8 & \\
\hline & \multicolumn{8}{|c|}{ cumulative } \\
\hline & $10 / 09$ & $11 / 10$ & $12 / 11$ & $13 / 12$ & $14 / 13$ & $15 / 14$ & $16 / 15$ & $17 / 16$ \\
\hline January & $-0,7$ & 22,0 & 8,3 & 11,0 & 8,0 & $-0,8$ & $-22,4$ & 17,9 \\
\hline February & $-1,4$ & 21,9 & 12,7 & 8,0 & 6,6 & $-3,6$ & $-10,7$ & 6,7 \\
\hline March & 6,1 & 21,0 & 12,4 & 4,8 & 8,5 & $-7,7$ & $-6,4$ & 9,2 \\
\hline April & 10,4 & 22,4 & 10,7 & 3,2 & 8,2 & $-5,8$ & $-7,5$ & \\
\hline May & 14,7 & 20,1 & 12,6 & 2,7 & 7,1 & $-8,5$ & $-4,5$ & \\
\hline June & 14,7 & 19,9 & 13,3 & 1,1 & 6,6 & $-8,3$ & $-2,5$ & \\
\hline July & 13,2 & 20,5 & 12,5 & 1,2 & 5,9 & $-9,5$ & $-3,7$ & \\
\hline August & 12,7 & 21,8 & 12,7 & $-0,6$ & 5,5 & $-8,8$ & $-2,4$ & \\
\hline September & 11,8 & 21,7 & 13,5 & $-0,5$ & 5,3 & $-9,5$ & $-2,8$ & \\
\hline October & 11,4 & 20,1 & 13,2 & $-1,3$ & 5,5 & $-8,3$ & $-2,9$ & \\
\hline November & 10,8 & 20,0 & 14,2 & $-0,9$ & 4,1 & $-8,5$ & $-1,8$ & \\
\hline December & 11,5 & 18,5 & 13,0 & $-0,4$ & 3,8 & $-8,7$ & $-0,9$ & \\
\hline
\end{tabular}

Source: TurkStat

In July, a total of 57 export goods declined by 55\%, but only exports of automotive and jewelry increased. Automotive sector increased its exports increased by 18.8 percent in the order of the most exported commodities and received the first order with $\$ 1,455$ million. In the second place, there is a jewelry sector that increased its exports by 216 percent with sales of $\$ 923$ million. Machine exports fell by 21.2 percent to $\$ 828$ million. Exports in the Turkish economy amounted to $\$ 142.5$ billion in 2016 , compared to $\$ 143.8$ billion in exports in 2015 , there was a $0.9 \%$ decrease in exports this year (see Table-4)

As for the imports of the year 2016, while China received the first place with $\$ 1,884$ million in imports in July, Germany ranks second with $\$ 1,722$ million. Third-order Russia imported $\$ 1.1$ billion. Unlike other countries, Russia did not enter the first twenty in exports, though it was among the top three in imports. 
Table 5. Percentage Change in Imports (2009-2016)

\begin{tabular}{|c|c|c|c|c|c|c|c|c|}
\hline & \multicolumn{8}{|c|}{ Year on Year } \\
\hline & $10 / 09$ & $11 / 10$ & $12 / 11$ & $13 / 12$ & $14 / 13$ & $15 / 14$ & $16 / 15$ & $17 / 16$ \\
\hline January & 26,0 & 44,6 & 3,3 & 7,6 & 2,6 & $-13,7$ & $-19,2$ & 15,9 \\
\hline February & 29,8 & 48,7 & 1,5 & 9,0 & $-6,0$ & $-7,1$ & $-8,0$ & 1,6 \\
\hline March & 42,8 & 44,1 & $-4,5$ & $-0,6$ & $-3,1$ & $-6,0$ & $-5,1$ & 6,9 \\
\hline April & 47,7 & 40,2 & $-8,0$ & 18,4 & $-9,5$ & $-11,1$ & $-11,9$ & \\
\hline May & 35,5 & 43,3 & 3,0 & 6,9 & $-10,2$ & $-14,4$ & $-3,8$ & \\
\hline June & 21,9 & 41,8 & $-5,4$ & 2,8 & $-1,0$ & $-12,5$ & 7,0 & \\
\hline July & 25,1 & 31,0 & $-1,1$ & 10,2 & $-13,2$ & $-8,6$ & $-19,4$ & \\
\hline August & 20,5 & 27,5 & $-4,3$ & $-3,3$ & 7,1 & $-18,1$ & 4,0 & \\
\hline September & 25,3 & 35,5 & $-6,0$ & 3,5 & $-0,1$ & $-25,2$ & $-0,7$ & \\
\hline October & 35,4 & 15,2 & $-5,7$ & 3,7 & $-1,5$ & $-11,8$ & 0,5 & \\
\hline November & 35,8 & 8,8 & 12,3 & 2,2 & $-0,1$ & $-25,3$ & 6,0 & \\
\hline \multirow[t]{3}{*}{ December } & 36,9 & 0,2 & $-3,7$ & 16,7 & $-5,8$ & $-17,4$ & 2,3 & \\
\hline & \multicolumn{8}{|c|}{ Cumulative } \\
\hline & $10 / 09$ & $11 / 10$ & $12 / 11$ & $13 / 12$ & $14 / 13$ & $15 / 14$ & $16 / 15$ & $17 / 16$ \\
\hline January & 26,0 & 44,6 & 3,3 & 7,6 & 2,6 & $-13,7$ & $-19,2$ & 15,9 \\
\hline February & 27,9 & 46,7 & 2,4 & 8,3 & $-1,8$ & $-10,5$ & $-13,6$ & 8,2 \\
\hline March & 33,3 & 45,7 & $-0,2$ & 5,0 & $-2,2$ & $-9,0$ & $-10,5$ & 7,7 \\
\hline April & 37,0 & 44,1 & $-2,4$ & 8,5 & $-4,2$ & $-9,5$ & $-10,9$ & \\
\hline May & 36,7 & 44,0 & $-1,2$ & 8,1 & $-5,6$ & $-10,5$ & $-9,5$ & \\
\hline June & 33,7 & 43,6 & $-2,0$ & 7,2 & $-4,8$ & $-10,9$ & $-6,6$ & \\
\hline July & 32,2 & 41,5 & $-1,8$ & 7,7 & $-6,1$ & $-10,6$ & $-8,5$ & \\
\hline August & 30,5 & 39,7 & $-2,1$ & 6,3 & $-4,7$ & $-11,5$ & $-7,1$ & \\
\hline September & 29,9 & 39,2 & $-2,6$ & 6,0 & $-4,2$ & $-13,1$ & $-6,5$ & \\
\hline October & 30,5 & 36,4 & $-2,9$ & 5,8 & $-3,9$ & $-12,9$ & $-5,8$ & \\
\hline November & 31,0 & 33,5 & $-1,6$ & 5,4 & $-3,6$ & $-14,1$ & $-4,8$ & \\
\hline December & 31,7 & 29,8 & $-1,8$ & 6,4 & $-3,8$ & $-14,4$ & $-4,2$ & \\
\hline
\end{tabular}

Source: TurkStat

In 2016, imports of $\$ 198.6$ billion were realized in the Turkish economy. When compared to $\$ 207.2$ billion of imports in 2015, there was decrease in imports by $4.2 \%$ in this year according to Table-5. Accordingly, imports in July 2016 decreased by 19.4 percent compared to the same month of the previous year. We can say that the increase in exchange rate is also effective in decrease in imports.

Thus, foreign trade deficit decreased by 32.5 percent to $\$ 4,788$ million. The July 15 coup attempt in foreign trade deficit and then the survivors were effective.

As of the end of 2013, when the Fethullahist terrorist organization began to surface, the current account deficit of the Turkish economy, which had a decreasing trend, decreased to 28.8 billion dollars by the end of July 2016 with the support of the decrease in oil prices in 
international markets. After July, the recovery trend on the current account deficit ended and the cumulative 12-month current account deficit increased by $\$ 33.8$ billion as of the end of October 2016. According to the Central Bank data, foreign exchange reserves including gold, which was $\$ 122.71$ billion as of July 15,2016 , decreased with the lowering of credit rating and decreased by two weeks after the coup attempt, reducing to $\$ 121.43$ billion as of 22 July and $\$ 119.72$ billion as of 29 July. Foreign exchange reserves, including the gold of the Central Bank, declined to $\$ 106.10$ billion by the end of 2016 . However, the price of Brent crude oil, which is at the level of 30 dollars at the beginning of 2015, rose to 50 dollars in the third quarter, causing the current deficit to go up to 33 billion dollars. In 2011, the ratio of current account deficit to Gross Domestic Product (GDP) was 9 percent, compared to 3.75 per cent at the end of 2015 . However, this rate again rose to 3.82 percent in the third quarter of 2016.

\subsection{Change in Employment and Unemployment Rate}

Table 6. Employment and Unemployment

\begin{tabular}{|c|c|c|c|c|c|c|c|}
\hline & & $\begin{array}{c}\text { Active } \\
\text { population }\end{array}$ & $\begin{array}{l}\text { Participation } \\
\text { rate to labor } \\
\text { force }\end{array}$ & $\begin{array}{l}\text { No of } \\
\text { Labor } \\
\text { force }\end{array}$ & $\begin{array}{r}\text { No of } \\
\text { unemp. }\end{array}$ & $\begin{array}{l}\text { Employ. } \\
\text { rate }(\%)\end{array}$ & $\begin{array}{c}\text { Unemploy. } \\
\text { rate }(\%)\end{array}$ \\
\hline 2014 & Yearly & 56.986 & 50,5 & 28.786 & 2.853 & 45,5 & 9,9 \\
\hline \multirow[t]{6}{*}{2015} & Yearly & 57.854 & 51,3 & 29.678 & 3.057 & 46,0 & 10,3 \\
\hline & January & 58.366 & 50,7 & 29.565 & 3.290 & 45,0 & 11,1 \\
\hline & February & 58.433 & 50,8 & 29.680 & 3.224 & 45,3 & 10,9 \\
\hline & March & 58.493 & 51,3 & 30.016 & 3.023 & 46,1 & 10,1 \\
\hline & April & 58.558 & 52,0 & 30.462 & 2.824 & 47,2 & 9,3 \\
\hline & May & 58.621 & 52,5 & 30.763 & 2.895 & 47,5 & 9,4 \\
\hline \multirow{10}{*}{$\frac{0}{\grave{0}}$} & June & 58.686 & 52,4 & 30.778 & 3.127 & 47,1 & 10,2 \\
\hline & July & 58.756 & 52,7 & 30.961 & 3.324 & 47,0 & 10,7 \\
\hline & August & 58.835 & 52,6 & 30.967 & 3.493 & 46,7 & 11,3 \\
\hline & September & 58.914 & 52,8 & 31.087 & 3.523 & 46,8 & 11,3 \\
\hline & October & 58.990 & 52,4 & 30.914 & 3.647 & 46,2 & 11,8 \\
\hline & November & 59.069 & 52,1 & 30.781 & 3.715 & 45,8 & 12,1 \\
\hline & December & 59.146 & 51,6 & 30.540 & 3.872 & 45,1 & 12,7 \\
\hline & Yearly & 58.720 & 52,0 & 30.535 & 3.330 & 46,3 & 10,9 \\
\hline & January & 59.493 & 51,5 & 30.658 & 3.985 & 44,8 & 13,0 \\
\hline & February & 59.567 & 51,8 & 30.855 & 3.900 & 45,3 & 12,6 \\
\hline
\end{tabular}

Source: Ministry of Development and TurkStat

When we look at the fluctuations in the unemployment rate from the basic macroeconomic variables representing the dissatisfaction or social unrest of the society for the same period, the unemployment rate, which was 10.7 percent in July 2016, rose to 11.3 percent in August, according to Table- 6 . The unemployment rate, which has been increasing due to the recruitment of women under the FETO/PDY, could have remained at 11.3 percent in 


\section{Mll Macrothink}

September due to the increase in employment in the agriculture and construction sectors, but rose to 11.8 percent in October. The seasonally adjusted unemployment rate rose to 11.7 percent in October. The unemployment rate, which was $10.3 \%$ in 2015 , rose to $10.9 \%$ in 2016 with a 0.6 percentage point increase.

When the effects of the coup attempt on the Turkish economy were examined with the daily selected macroeconomic variables, the daily effects were observed in the financial markets in the week of 18-22 July following the coup attempt. In the following weeks, these losses were gradually eliminated. Quarterly, i.e. quarterly impacts, became more evident as a result of the coup attempt, as Turkey's credit rating was lowered by Moody's on September 23 below the investment grade. The destabilization of the confidence of the Turkish economy at the level of foreign investors and the increasing uncertainty contributed to the negative impact of Turkey's fluctuations on the world markets compared to similar developing countries, with the contribution of the ongoing propaganda activities of disregarding Turkey of FETO/PDY.

\subsection{Changes in Stock Exchange, Interest Rates and Exchange Rate}

Following the July 15 coup attempt, downward trends were observed in the financial markets on the week of 18-22 July. According to the figures, the Bist-100 Index in Stock Exchange Istanbul lost 13.4 percent in the week of 18-22 July, while the average loss rate in Stock Exchange in dollar terms was realized as 18.1 percent (see Figure-1). The benchmark bond interest rate, which was 8.55 percent at the close on Friday, July 15, rose to 9.37 percent at the end of Friday, July 22, under the influence of sales-led cycles in government domestic debt securities. However, within the scope of the simplification policy, the Central Bank has received six interest reduction decisions throughout 2016.
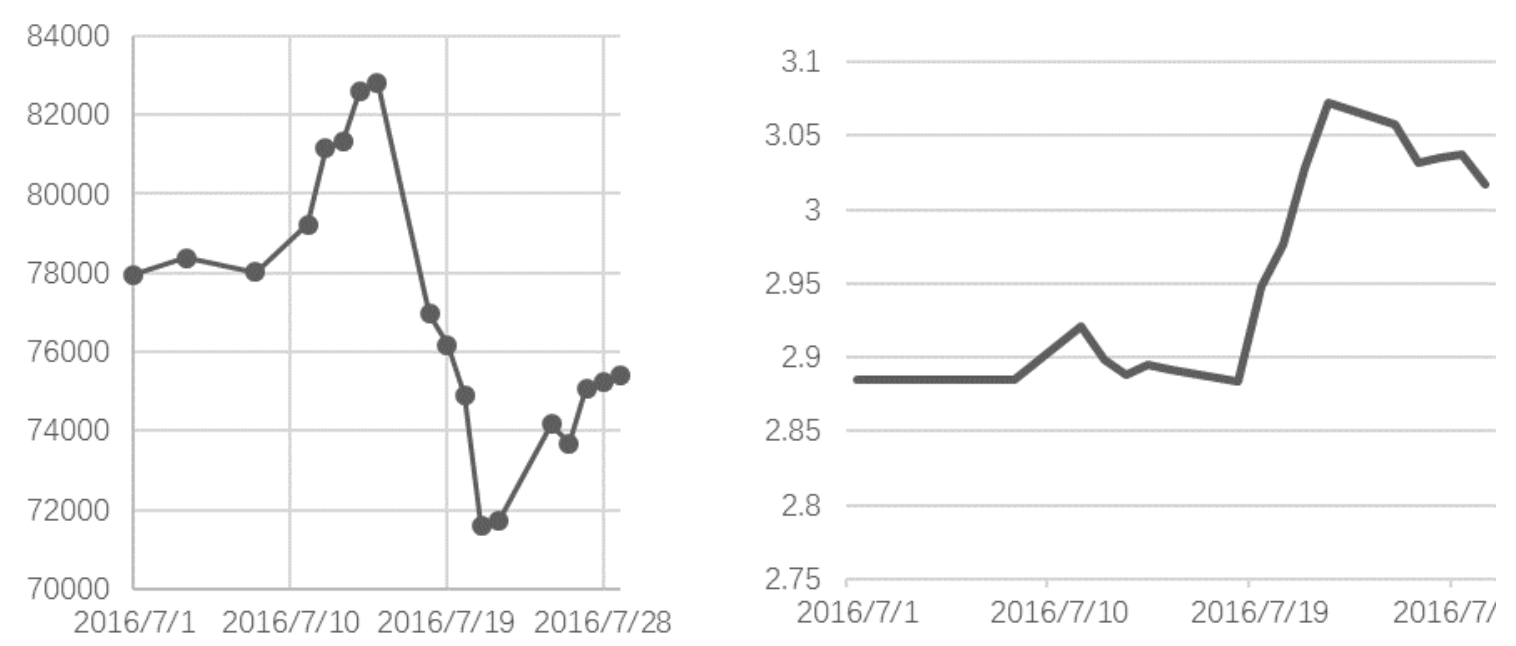

Figure 2. July 2016 BIST100 index changes(left) and the US dollar rate (right)

After the coup attempt, very fluctuating course was recorded in foreign exchange markets. At the end of July 15, the USD / TL rate, which was at 2.89, rose to 3.77 at the end of July 22, while the Euro / TL rate rose from 3.20 to 3.37 (see Figure-2). As the Turkish lira recorded a 
sharp decline, the Turkey's Central Bank (CBRT) made a written statement on Sunday and the CBRT stated that the necessary liquidity would be provided to the banks without limits and that all measures would be taken to protect financial stability if necessary.

After the coup attempt, losses on many markets between 18-22 July have been compensated for in the following weeks. In the recovery process, the Turkish people 's courage against the treacherous coup attempt and their union movement supported the recovery of the perceptions of the Turkish economy. Moreover, in July, August and September, the total amount of Foreign Exchange Deposits accounts in the Turkish banking sector decreased. According to Banking, regulation, and Supervision Agency(BRSA) data, 18.0 billion of Turkish Lira(TL) the decrease corresponding to 21.7 billion TL recorded in the total amount of foreign exchange deposit accounts in 3 months is realized in time deposit / participation fund accounts. Despite the increase in foreign exchange rates, the decrease in the amounts of foreign exchange deposits, i.e. foreign currency deposits / participation fund accounts, shows that Turkish people support the Turkish Lira by selling foreign exchange after the coup attempt.

\section{The Microeconomic Effects of the FETO/PDY on the Companies and Institutions}

FETO/PDY has emerged that consists of a complex and extensive structure that houses banks, universities, schools, dormitories, schools, media organizations, printing, publishing, cargo companies and other commercial companies, which have economic value of 150 billion dollars both in Turkey and in the world.

A number of operations were carried out on the foot of the FETO/PDY, which the government held responsible for the coup attempt on July 15th, was associated with the private sector. The number of companies handed over to the Savings Deposits Insurance Fund SDIF after the completion of the operations reached 858. As the companies and their owners operating in all regions of Turkey continued to conduct investigations, an uncertainty about the future of these companies began to emerge. However, there is uncertainty about this issue by clarifying what the companies will be with a decree of the law "KHK" published by the government.

On December 6, 2017, it was stated that in the repetition of the Official Gazette, Article 81 of Decree No. 680, the Minister who is responsible for SDIF decided to sell the companies transferred to the Savings Deposits Insurance Fund due to the relationship with the terrorist organizations of the FETÖ/PDY.

According to the Decree in the Law, "Except the companies which are closed in accordance with the statutory decrees enacted within the scope of the state of emergency declared by the Council of Ministers dated 20/7/2016 and numbered 2016/9064 and transferred to the General Directorate of Vakiflar or to the Treasury; The companies covered by the first and second paragraphs shall be managed by the managers appointed by the Minister to be associated with the Savings Deposit Insurance Fund under the supervision of the Savings Deposit Insurance Fund in accordance with commercial practices and as an indissoluble 
merchant till the end of the investigation and prosecution. The managers of these companies are appointed by the Minister to be associated with the Savings Deposit Insurance Fund and are removed from the office.

The Minister responsible for SDIF may decide on the sale or liquidation of the assets of the company or assets or the property values specified in the tenth paragraph of Article 128 of Law 5271.

In the course of the investigation of the FETO/PDY, it was said that the loss of the companies transferred to the Savings Deposit Insurance Fund (SDIF) would be sold and the others would be managed by the SDIF until the end of the trial. However, it is thought that the dismantling companies or the companies operating on the sensitive area are also being removed or transferred.

As of March 2017, the companies transferred to the SDIF had 858 companies, with an asset size of 40.5 billion TL and an equity capital of 18.1 billion TL. Since how many of these companies will continue to operate or to be liquidated is not yet disclosed; the interruption of the activities of the transferred companies, the lenders, and the presence of customers and employees who are at risk of becoming unemployed create a certain amount of uncertainty in the markets. The fact that there are more than 44 thousand employees in the transferred companies and the unemployment rate which has been rising since the coup attempt, when some of these employees are thought to be unemployed, will rise up a little. Also, it may not be easy to sell some of the companies transferred to the Fund at reasonable prices. However, the extent to which confiscated companies will affect economic stability in a negative way will result in the determination of the end result of the inventory work that companies will have a significant role in the economy, and that part of the economy will be the sign company, that is to say, liquidate. It would be very limited for these companies to have a negative impact on the stability of the economy, as it is thought that a significant portion of the companies that are active will be transferred in a short time and easily, while the liquidation of signposted signage companies does not have any effect on economic activities.

The first company transferred to the Fund was "Boydak" Holding, one of Kayseri's long-established companies, employing 13,000 people with a population of approximately 6 billion pounds. Founded in 1957 in Kayseri, the holding has 34 companies in 7 different sectors ranging from furniture to textiles, chemistry, iron and steel to logistics and energetic intelligence. Companies such as "İstikbal", "Bellona", "Mondi", "Boyteks" and "Form Sünger" are among the most important brands of the holding. In addition, the Holding, which houses organizations such as "Merkez Çelik" and "Boytaş", are listed on the list of Turkey's top 500 industrial companies, which is announced by the Istanbul Chamber of Industry, with 6 companies and 1 company on the second largest industrial corporation list.

"Naksan", who ranked second after "Boydak", was the group with the most companies. 51 companies of the "Naksan Group", which has an asset size of 6.8 billion pounds, a pound of 1.2 billion pounds, a core pivotal of 1.3 billion pounds, and approximately 3800 employees, were transferred to the Fund. 


\section{Ml Macrothink}

There are 18 companies with a value of $\$ 10$ billion and the groups that have gone to the Fund within "Koza Ipek" Holding. In 1948, "Koza Altın İşletmeleri A.Ş.", "Kofa Altin İşletmeleri AS”, "İpek Doğal Enerji Kaynakları Araştırma ve Üretim AŞ”, "Koza Prodüksiyon ve Ticaret AŞ", "Rek-tsur Reklam ve Pazarlama Ticaret Şirketi” ve "Ípek Online Bilişism Hizmetleri" etc., were established by "Koza Davetiye" by businessman and printer Ali İpek.

Another company transferred to the Fund is "Kaynak" Holding. This holding has 31 companies operating in 16 different sectors. While Holding operates in the field of education such as "Fem" and "Güvender Dersaneleri", there are companies that produce educational materials such as books, stationery materials. "NT" Stores, "Zambar" Publications are only two of these. In addition, "Sürat Kargo" is one of the most known brands of the band. The total number of employees of "Kaynak" Holding, which is about 10 employees, is around TL 1.5 billion a year.

\section{Conclusion}

The July 15 coup attempt, which surfaced since December 2013, did not create lasting effects or damage to macroeconomic variables such as production, capital flows, exports and imports, but short-lived volatility. Especially the daily interest rate, exchange rate and the effect on the Istanbul Stock Exchange have appeared as a short period of fluctuation.

The short (daily) and medium (quarterly, annual) term effects on the Turkish economy of the FETO/PDY have been limited and permanent. The most important reason for this is the integration of Turkish people and politics in the face of the terrorist organization. However, those who manage the economy, the bureaucrats, the president of the central bank and the businessmen's statements that support the confidence environment and the strong policy impact prevented the economy from entering the uncertainty process.

The Turkish government try to eliminate the economic traces of the failed coup by taking decisions on "Economic Prospects Package", "Program of Attraction Centers of Eastern and Southeastern Anatolia Region and Investment and Support Progression", "Economic Coordination Board" for the real sector and labor market and by putting into operation some important transportation projects as well.

\section{References}

Grant National Assembly of Turkey, "Report Parliamentary Investigation Commission of 15 July 2016 of the coup attempt of Fethullahçı Terrorist Organization (FETO/PDY)". $\begin{array}{lllll}\text { Retrieved } & 1 & \text { June } & 2017 & \text { from }\end{array}$ https://www.tbmm.gov.tr/develop/owa/komisyon_tutanaklari.tutanaklar?pKomKod=102 $1 \& \mathrm{pDonem}=26$.

International Monetary Fund. IMF Country Report No. 16/104 retrieved 15 June 2017 from 
https://www.imf.org/external/pubs/ft/scr/2016/cr16104.pdf

Karagol, T. E. (2016). 15 Temmuz Darbe Girişimi Ve Türkiye Ekonomisi. Adam Akademi, $6(2), 37-50$.

Kayhan S., \& Kar, M. (2016). Resilience of the Turkish Financial System to Failed Coup Attempt", bilig, Autumn / 2016/ Number 79 275-291. Retrieved 25 May from http://bilig.yesevi.edu.tr/index.php?menu_v=onceki_sayilar_alt\&ilgili_sayi=149

Ministry of Development, Economic and Social Indicators. Retrieved 30 June 2017 from http://www.mod.gov.tr/Pages/EconomicandSocialIndicators.aspx

Tatliyer, M., \& Gür, N. (2016). "The Resilience Of The Turkish Economy After The Failed Coup Attempt Analysis” SETA Analysis, August 2016 No: 20. Retrieved 1 June 2017 from

http://file.setav.org/Files/Pdf/20160810112254_the-resilience-of-the-turkish-economy-af ter-the-failed-coup-attempt-pdf.pdf

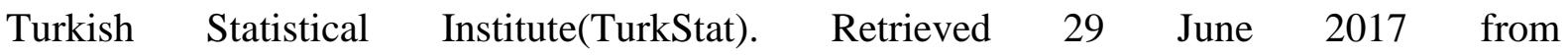
http://www.turkstat.gov.tr

Ünay, S., \& Dilek, Ş. (2017). “15 Temmuz: Başarisiz Bir Darbe Girişiminin Ekonomi Politiği”, SETA Analysis, January No: 184. Retrieved 26 May 2017 from https://setav.org/assets/uploads/2017/01/15temmuzekonomipolitik.pdf

\section{Notes}

Note 1 . It is shortly called as OHAL in Turkish.

Note 2. TURKSTAT revised the calculation method of GDP in accordance with the National Accounts System (SNA-2008) and the European Accounting System (ESA-2010). In this framework, growth figures previously announced at fixed prices have started to be calculated according to the chain volume index $(2009=100$ basis $)$ method

\section{Copyright Disclaimer}

Copyright for this article is retained by the author(s), with first publication rights granted to the journal.

This is an open-access article distributed under the terms and conditions of the Creative Commons Attribution license (http://creativecommons.org/licenses/by/3.0/). 